Article

\title{
Memorial Traces as Tropes of Postcolonial Hauntings in Robert Lalonde's Sept Lacs plus ou Nord and Nina Bouraoui's Mes mauvaises pensées
}

Jasmina Bolfek-Radovani ${ }^{1, *}$

How to cite: Bolfek-Radovani, J. 'Memorial Traces as Tropes of Postcolonial Hauntings in Robert Lalonde's Sept Lacs plus au Nord and Nina Bouraoui's Mes mauvaises pensées.' London Journal of Canadian Studies, 2018, 33(1), pp. 94-110. DOI: https://doi.org /10.14324/111.444.1jcs.2018v33.007.

Published: 14 November 2018

\section{Peer Review:}

This article has been peer reviewed through the journal's standard double-blind peer-review, where both the reviewers and authors are anonymized during review.

\section{Copyright:}

(C) 2018, The Author(s). This is an Open Access article distributed under the terms of the Creative Commons Attribution License (CC-BY) 4.0 https://creativecommons.org/licenses/by/4.0/, which permits unrestricted use, distribution and reproduction in any medium, provided the original author and source are credited $\bullet$ DOI: https://doi.org/10.14324/111.444.ljcs.2018v33.007.

\section{Open Access:}

London Journal of Canadian Studies is a peer-reviewed open access journal.

\footnotetext{
*Correspondence: j.bolfek-radovani@qmul.ac.uk

${ }^{1}$ Queen Mary University of London, UK
} 


\title{
Memorial Traces as Tropes of Postcolonial Hauntings in Robert Lalonde's Sept Lacs plus au Nord and Nina Bouraoui's Mes mauvaises pensées
}

\author{
Jasmina Bolfek-Radovani
}

\begin{abstract}
This article is a comparative analysis of the language of memory in two auto-fictional narratives by two postcolonial francophone authors of mixed background, belonging to the area of Québec (Robert Lalonde) and Algeria (Nina Bouraoui). It will be argued that both authors seek to deconstruct the binary relationship of the spaces and identities they each belong to (white-Amerindian for Robert Lalonde vs. Franco-Algerian for Nina Bouraoui) through a specific poetics of writing or language of memory. At the same time, they each return cyclically in their writing to the postcolonial spaces, memories and histories of their respective nonWestern cultures, as if 'haunted' by these spaces. Using the method of close textual reading in a comparative postcolonial francophone context, the article aims to show how the language of memory is deployed in the two narratives chosen. It demonstrates that both authors use the figure of the memorial trace as a trope of haunting in order to construct that language. It concludes that the figures of memory identified in the two texts analyzed give rise to a series of 'postcolonial hauntings' producing a postcolonial discourse of ambiguity rather than resistance.
\end{abstract}

Keywords: postcolonial, francophone, space, memory, trope, haunting, White-Amerindian, Franco-Algerian, Robert Lalonde, Nina Bouraoui 


\section{Introduction}

In the analysis that follows, I will use the method of close textual reading combined with an anthropological and postcolonial perspective to uncover the presence of the memorial traces and the tropes of haunting underpinning the language of memory in two auto-fictional narratives by Robert Lalonde (Québec) and Nina Bouraoui (France-Algeria). Memorial trace is understood here as both absence and presence. It is conceived as a residual presence of the repressed memories capable of returning to the surface of consciousness through the gradual processes of re(-)membering. The trope of haunting is viewed as a literary device, aimed at expressing the recurrent resurgence of these memories. Its meaning can be associated with that of the concept of 'stillness' as defined by the Greek anthropologist Nadia Seremetakis in her conceptualization of sensory memory. I will try to demonstrate in the analysis conducted that the tropes of haunting in the two texts chosen are expressed through a number of recurring figures of memory. One feature that these two authors share in common is that they both cyclically return to their native spaces as if haunted by them. One can claim that in both cases the need for a re-appropriation of identity passes through the need for a re-appropriation of native space (Oka for Lalonde and Algeria for Bouraoui). However, the constant movement in writing between the two poles of identity, with their dual memories and histories, creates a writing position of ambiguity embedded in the contradictions that follow from assuming a mixed identity and heritage. By placing myself within the larger context of postcolonial discourse theory, I am posing the question of whether narratives of 'postcolonial hauntings' can be fully inscribed within a postcolonial discourse of resistance, or whether they can be ascribed to a postcolonial discourse of ambiguity. My article concludes that the tropes of haunting identified in the two chosen texts generate a postcolonial discourse of ambiguity rather than resistance. ${ }^{1}$ Whilst Lalonde succeeds in recovering the latent memories of his paternal Amerindian past through a re-inscription or a re-mapping of the Amerindian space of the North, Bouraoui fails to reconcile fully her paternal (Algerian) with her maternal (French) heritage, as she can only do so by a symbolic passage through the (post)colonial space of Paris. Nevertheless, both authors share a propensity towards a cyclical return to the exploration of native space in their writing, something that produces a language of memory punctuated by tropes or sites of haunting. These tropes can be viewed as manifestations of a dynamics of 'return of the repressed' at the level of the narrative in the two texts chosen. 


\section{Tropes of haunting in Robert Lalonde's Sept Lacs Plus au Nord (1993) and Nina Bouraui's Mes mauvaises pensées (2005): the image of the 'Indian' vs. the spectre of Algeria}

The concept of the retour du refoule or 'the return of the repressed' is a key concept examined in Pascal Blachard, Nicolas Blanchel and Sandrine Lemaire's work on French colonial memory. ${ }^{2}$ It is discussed at length in the context of the authors' discussion on France's colonial memory and nostalgia, notions that were at the centre of France's colonial discourse of the nineteenth century, embedded in the ideological values of the Third Republic. ${ }^{3}$ Indeed, the main question posed in Nina Bouraoui's texts with an Algerian theme is how one is to conceptualize the (post)colonial experiences of space, place and spatial loss in the context of Franco-Algerian culturally conflicting, multiple memories and histories. ${ }^{4}$ In Bouraoui's novels, the 'return of the repressed' manifests itself through the recurrent appearance of memorial traces as postcolonial hauntings that punctuate all of her texts dealing with Algeria. Algeria becomes a spectre, a haunting absence/presence in her writing, as well as a source of creative inspiration. In other words, Bouraoui's excavatory memories of Algeria, a space that she is haunted by, can be viewed as a symptom of the retour du refoule in the societal, political and cultural contemporary spaces of France, and as analyzed in Blanchard, Bancel and Lemaire's work. Equally, in Robert Lalonde's text, the sudden reappearance of the image of his Indian friend in the news television report symbolizes a moment in which the main character's repressed memory breaks through to the surface of consciousness. These repressed memories come back to haunt the main character in a moment that reawakens his early memories before his return to the native town of Oka. Furthermore, the two texts chosen remind us that it is through awakening of sensory memory in moments of 'stillness' that the re-appropriation of one's own identity or history can really begin to take place and one can start to make sense of one's own fractured past. This concept of stillness is defined by Seremetakis as follows: 'Stillness is the moment when the buried, the discarded, and the forgotten escape to the social surface of awareness like life-supporting oxygen. It is the moment of exit from historical dust. ${ }^{5}$ It can therefore be advanced that the language of memory examined in the two texts chosen is deployed through the sudden resurgence of forgotten and marginalized (Aboriginal vs. Algerian) memories and histories brought to the surface in a moment (or moments) of 'stillness'. Both narratives show the importance that sensory memory can play in the (de)construction of dual memory and identity 
that characterizes authors of mixed heritage. Yet, while Lalonde succeeds in recovering the repressed memories of his paternal Amerindian past through a re-inscription and re-mapping of the Amerindian space of the North, Bouraoui does not fully manage to incorporate her Algerian past and the paternal space of Algeria into her contemporary identity. She fails to reconcile her paternal (Algerian) with her maternal (French) heritage, as she can only do so by a symbolic passage through the (post)colonial space of Paris. Instead, her lesbian and cosmopolitan identity is recovered fully through the appropriation of a third space - the North American space of Provincetown.

In the context of Québec, the case of the Métis author and actor Robert Lalonde, who does not specifically identify himself as being Métis and positions himself as a Québécois author, has particular significance for the issue of cultural memory and how writers with a bilingual/ bicultural heritage might explore this question. A quarter Métis, Robert Lalonde was born in the town of Oka in 1947 and graduated from the Montréal Conservatory of Arts and Drama in 1970. An acclaimed writer, actor, playwright and academic, he published his first novel in $1981 .^{6}$ Lalonde's writing project, as he himself explains, can be best defined as his quest for a space in which the reconciliation (and not opposition) of his 'deux façons de vivre' (two ways of living) or 'deux façons d'être' (two ways of being) is possible. ${ }^{7}$ If his work can be said to alternate between the particular and the universal, the semi-autobiographical text Sept Lacs plus au Nord belongs within the suite of texts that can be called an exploration of the theme of indianité. ${ }^{8}$ In the text, Lalonde explores questions of loss and recovery of Amerindian memory and collective imaginary and reflects on his own Amerindian family heritage. ${ }^{9}$ Sept Lacs plus au Nord is a semi-autobiographical story of Michel du Bria, a Métis writer living in Montréal, who returns to his native town of Oka a year after the eruption of the Oka crisis and undertakes a voyage with Angèle, his mother, up north. The setting off by car of the two protagonists marks the beginning of Michel's internal spiritual voyage on a path of family and ancestral re(-)membrance that culminates with their arrival at their final destination, Lake Camachigama, situated in the region of AbitibiTeminscamingue, where Michel's teenage friend and lover, named as 'the Indian', awaits him. The Oka crisis that forms the political backdrop of the novel is a site of contested memories and identities that still resonates in the collective consciousness and memory of both the Québécois and the Canadian population. ${ }^{10}$ While the events of the Oka crisis can be said to have galvanized the Canadians' and the Québécois' preoccupation with the question of the status of the Aboriginal people, they also had some 
longstanding consequences on the types of collective memory generated within the Mohawk and the white communities in Québec. This has led to the production of an 'excess' of meaning and memory that could be observed in the articles that the Québécois press devoted to the analysis of the conflict surrounding the Oka crisis on the eve of its 20th anniversary (11 July 2010) and the comments posted at that time by its readers on the newspaper's website. ${ }^{11}$ Interestingly, although Oka represents the main topic space in Sept Lacs plus au Nord, Lalonde only occasionally refers to the events of the Oka crisis in the course of the novel. If this absence can be interpreted as the author's need for assertion of a poetics rather than a politics of identity, it can also be seen as a sign of fragmentation of both personal and collective memory, or a sign of the authornarrator's impossibility to make full sense of the events that took place during the crisis. Indeed, as Lalonde explains in an interview given to the newspaper Le Devoir when talking about the book and relaying his own experience of the crisis:

C'est un road-book où j'aborde de biais la crise d'Oka. Cette crise m'a stupéfié tout le temps qu'elle a duré. Tout le monde était à la fois d'un côté et de l'autre et on me disait: s'il y a quelqu'un qui peut dire quelque chose là-dessus c'est toi. Mais, moi, je n'en pensais rien, j'étais bouleversé, mais sans arriver à faire la part des choses. ${ }^{12}$

It's a road novel in which I address the Oka crisis indirectly. This crisis stupefied me during all the time it lasted. Everyone was taking sides on both sides of the conflict and people were telling me: if anyone can say something about it it's you. But, I could not think about it, I was overwhelmed, unable to put things into perspective. ${ }^{13}$

Yet, in a more recent interview, the author does seem to offer a more direct answer to the question of how one can integrate one's own fractured experience of the past in the context of a traumatic event. As Lalonde states: 'Je crois qu'on peut sortir d'un malaise, en retournant géographiquement sur les lieux où la souffrance est née' (I think one can overcome a difficult experience by returning to the original place where the suffering took place) ${ }^{14}$ Thus, as Lalonde seems to be saying, the reconciliation of the two opposing poles of identity and the recovery of identity loss can be achieved through the return to the original place of trauma or fracture. A gradual recovery or a rewriting of individual memory can become possible through the activation of the sensory processes of remembrance and the embodied re-experience of the place that has been lost, both physically and symbolically, as will be shown in the analysis of Lalonde's text that 
follows. One of the main tropes of haunting, the figure of 'l'Indian' (the Indian) appears at the beginning of Sept Lacs plus au Nord as a returning ghost from the narrator's past. At the beginning of the text, the reader learns that Michel briefly sees 'the Indian' in a television news report on the Oka crisis some time before he decides to return to the village of Oka. This pivotal moment sets the narrative in motion and is experienced as a shock by Michel, who was separated from his friend before being sent off to college. The mediatization of the Oka crisis and the demonization of the image of the 'savage' Mohawk Indian (an image that was often exploited by the media during the crisis) stands in contrast to the image of the heroic white soldier:

Et il y avait l'Indien, bien sûr. Une seule fois, il l'avait aperçu aux nouvelles, à la télévision: adossé au tronc d'un gros pin, il pleurait, sans se cacher le visage, comme autrefois. L'image est passée très vite, tout de suite ils ont montré à nouveau les guerriers masqués, les barbelés, le soldat blond, héroïque, propre, debout devant son ennemi noir, le Mohawk, le warrior sanguinaire, affrontement de cowboys et de sauvages des vieux films, la drôle de guerre au jour le jour, dans la pinède. ${ }^{15}$

And then there was the Indian of course. Only once did he see him on the television news: he was leaning against the trunk of a large pine tree, he was crying without hiding his face like in the old days. The image was gone very quickly, straight after they showed again the masked warriors, the barbed wire, the soldier with the blond hair, heroic, clean, standing in front of his black enemy, the Mohawk, the bloodthirsty warrior, a confrontation between cowboys and savages from old movies, a phoney war unrolling from day to day in the pine wood.

More importantly, this brief moment of visual identification of the suppressed yet never forgotten figure of his friend 'l'Indien' is sufficient to awaken suddenly Michel's teenage experience of a critical transformation that occurred in a crucial moment of self-identification with the Indian after his inclusive use of the pronoun 'us': "What's wrong with us?" Il avait dit "with us", et non "with them" et il avait pleuré, pour la première fois' ('What is wrong with us?' He said 'with us', and not 'with them' and he cried for the first time). ${ }^{16}$

As in many other passages throughout the book, it is through sensory or corporeal memory that Michel's suppressed, dis-membered memories become re-membered, and that he is able to access self-knowledge 
and make sense of the fractured experiences of his past. Lalonde touches here on the important problem of the connection between the political and the poetic, thus posing the question of 'how the political is experienced on the level of the senses', a question that Seremetakis raises in her introduction. ${ }^{17}$ In her study of the connection between the political and the poetic in everyday life and the conceptualization of sensory memory, Seremetakis argues for the inclusion of the concepts of perception and memory in the study of (material) culture. She observes that the study of these concepts often remains marginalized by ethnographers and sociologists fixated on the exploitation and study of the literal materiality of artefacts and cultural objects. ${ }^{18}$ Departing from the example of the loss of sense of taste and the self-imposed experience of tastelessness in 'cultures that undergo colonial and post-colonial experiences of transformation', Seremetakis advances that the discourse on loss propagated through public culture fulfils an ideological function in order to present a normative, modernist view of the present, and push into the sphere of private experience all knowledge that is no longer publicly accepted by this prevalent ideology. As she explains further, this compartmentalization and scientific rationalization of the senses is particularly characteristic of a culture of modernity, as the senses are 'externalised as utilitarian instruments'. In fact, the study of perception and memory as 'embodied acts and semantically dense objects' can reveal that 'there are substances, spaces and times that can trigger stillness'. Seremetakis's idea of stillness as a simultaneous moment of temporary cultural suspension and of 'exit from historical dust' seems particularly relevant to the analysis presented here. Michel's return to his native space, a space of wilderness and recovered corporeality, can be said to embody this space of stillness in the sense that Seremetakis gives it. The feeling of exhilaration and recovered corporeality (previously divided between city and nature) is expressed by Michel in the following passage: 'Un desserrement délicieux, les valves du cœur qui travaillaient formidablement, l'air presque liquide du matin qu'il buvait sans s'étouffer. Il pensait: “Je retrouve mon corps", comme s'il l'avait perdu' (A wonderful feeling of relaxation, the heart valves working perfectly, the almost liquid morning air he was drinking without suffocating. He was thinking: 'I have recovered my body,' as if he had lost it) ${ }^{19}$ Michel's suppressed Amerindian nature that is represented symbolically in the figure of 'l'Indian' is tied to his sense of loss of corporeality that can be only recovered through the recovery of Michel's sensory memory. As in the examples cited, Lalonde's novel is permeated by numerous, sometimes ambiguous, references to the Indian that becomes a symbol of Michel's lost Amerindian self coming back to haunt him after 30 years of his absence 
from the town of Oka. It has to be noted here that the figure of the Indian appears in Allende's earlier novel Le Denier Été des Indiens; it can therefore be interpreted as the first part of Sept Lacs plus au Nord. ${ }^{20}$ The text of the 1982 novel begins with the words: 'Je ne sais pas pourquoi mais, encore aujourd'hui et les yeux fermés, je continue de le voir' (I don't understand why but, even today if I close my eyes I can still see him). The alternation between the depersonalized use evident in the expression 'the Indian' and the act of referring to him as Kanak, contribute to a sense of ambiguity present in Michel's early experiences of meeting with him and his Amerindian friends. One can conclude from this that a double haunting is at work in Sept Lacs plus au Nord; the haunting figure of the Indian takes the form of a symbolic absence, as it has become emptied of its materiality through the later process of narrativization of Michel's experience of (cultural and personal) loss. Hidden behind this symbolic absence however, resides an older, fantasized absence that begins to haunt Michel at the end of Le Dernier Été des Indiens. In this context, the absence of any mention of the Indian's name in Sept Lacs plus au Nord is significant; he has fully become a symbol, a trace, a haunting ghost of the repressed Amerindian collective past. By omitting to name Kanak in Sept Lacs plus au Nord, Lalonde's text installs a discourse of ambiguity at the centre of the novel that can be interpreted as a consequence of his divided or dual identity and heritage.

It is towards the middle of the novel the reader learns that the only material trace that 'l'Indian' leaves behind is a letter addressed to Michel that he handed over to Angèle while in hiding during the Oka crisis. Michel and Angèle travel up north, passing through seven geographic points or lakes located in an imagined space of the North that is neither fully specified nor fixed; instead it becomes fluid, dynamic and relational. The seven geographic locations of the lakes primarily fulfil a symbolic function: they represent the seven physical, mental and spiritual places of Michel's journey through time and space whose progression can be tracked through the material passage of these seven locations. The moment of revelation of the existence of the Indian's letter marks both the physical and the symbolic starting point of the process of Michel's rebirth, compared to Orpheus' return from the world of the dead: 'Il se sentait nettoyé, neuf, transporté facilement dans le paysage, comme Orphée qui serait remonté, impuni, des Enfers' (He was feeling purified, new, transported easily to the landscape as if he was Orpheus returning unpunished from Hell). ${ }^{21}$ Lalonde's reference to the figure of Orpheus as the one that comes back from the dead (and possesses transformative and purifying properties) has specific cultural resonances in the Amerindian imaginary. It refers to 
an important myth that is prominent in the Iroquois native mythology tradition and that the Mohawk share with the Iroquois peoples (as one of the five tribes belonging to that group). Three main types of myths play an important role in the religion of Aboriginal people in general: the 'creation myths', the 'trickster myths' and the 'transformation myths' ${ }^{22}$ Another type of myth is the 'culture hero myths', reminiscent of the Greek myth of Orpheus. In these Orpheus-type myths, the 'culture hero' makes a dangerous journey to the world of the dead to bring back a deceased loved one. In native mythology, the world of the dead, which is believed to lie at a great distance from the world of the living, can only be reached after a difficult and perilous (spiritual and physical) journey. The resemblance between Michel's journey and that of the figure of the culture hero as developed in Aboriginal native mythology is striking. Michel's quest with his mother, Angele, takes on the form of a difficult spiritual journey that leads him to the symbolic world of the dead (the world of forgotten memories where the Indian resides), bringing back his memories of the Indian and, by extension, of Amerindian heritage and culture - from the world of the dead into the world of the living. The spatial journey that Michel and his mother undertake to meet 'l'Indian' coincides with Michel's internal journey and return to his suppressed Amerindian origins.

In postcolonial theory, the concept of haunting is often used to emphasize the importance it plays in the recovery of occulted colonial histories and memories, as discussed by Michael F. O'Riley. ${ }^{23}$ However, as the author argues, the use of the concept of postcolonial hauntings in postcolonial discourse theory can be problematic from the point of view and position of the postcolonial critic conducting her/his situated reading. ${ }^{24}$ Very simply expressed, at the center of O'Riley's argument lies the question of whether a recovery of occulted colonial histories is fully possible, something that becomes problematic because of the way in which both 'place' and the subject's 'position and agency' are defined. If Lalonde's novel reminds us that a reconciliation between Amerindian and nonAmerindian memory in the context of Québec can be realized, the novel Mes mauvaises pensées by the Franco-Algerian writer Nina Bouraoui, explores the deconstruction of dual identity in the context of the postcolonial binary pair France-Algeria. The question that is posed here is to what extent Bouraoui seeks to deconstruct the binary relationship FranceMaghreb through her search for and engagement with 'third' cultural and geographic spaces (either Mediterranean, as in Garçon manqué, or North American, as in Mes mauvaises pensées) and if so, why she cyclically returns to the space and imagination of Algeria in her writing. The FrancoAlgerian writer Nina Bouraoui was born in 1967 in Rennes, France, of an 
Algerian father and a French mother. Between years 1970 and 1980 she lived in Algeria, and at the age of 14 returned to France. She currently resides in Paris where she first became known for her text from 1991, La Voyeuse Interdite, a text that promoted her to the label of a Beur or second generation immigration writer, a label that can no longer be attributed to her work. Mes mauvaises pensées is the author's penultimate novel, belonging to the series of texts that explicitly deal with an 'Algerian theme'. ${ }^{25}$ As has been argued by a number of critics, the classification of Nina Bouraoui as a writer within a defined literary space is problematic; although she is a writer whose imagination is deeply rooted in the Algerian imaginary, an imaginary to which she constantly returns, as already stated, she also likes exploring the space of Western culture and its cosmopolitan and urban identities. ${ }^{26}$ Similarly to Lalonde, she has developed a style that is classical and lyrical, but also impregnated with sensuality. Throughout Bouraoui's work, one can unveil a discourse on migrant identity in her writing that is reframed within the imagination of the South. Defining herself as a 'sujet sans racines profondes' (a subject without deep roots), the narrator uses her Algerian heritage as the site of an imagined Southern identity that becomes the source of the narrator's 'rêves orientaux' (Oriental dreams) viewed as Oriental hauntings. ${ }^{27}$ In this context, the narrator's dual self becomes a literary self, constantly reinvented on the backdrop of the narrator's Algerian paintings or 'tableaux Algériens'. ${ }^{28}$ However, her dual identity is not entirely unproblematic, something that leads to the creation of a postcolonial discourse of ambiguity in Mes mauvaises pensées. Indeed, already in her 2000 novel, Garçon manqué, the young narrator speaks of the complex identity fracture that she experiences when she exclaims: 'Mon corps se compose de deux exils' (My body is born of two exiles). ${ }^{29}$ This divided position that is part of the experience of possessing a dual or mixed heritage is fundamental to Bouraoui as a writer; she will ultimately seek to deconstruct this dual position in Mes mauvaises pensées. The novel is set in the closed, confined space of a psychoanalyst's office in Paris, in which a young Franco-Algerian woman writer works through her childhood and adulthood memories and experiences, after having felt she was being obsessed by 'des mauvaises pensées'. From the first lines of the text, the reader enters the intimate and dark space of the narrator and her confession about the 'bad thoughts' of a foreign, repressed self by which she is possessed. Here, the language of memory is deployed through a multiple layering of the different memorial traces manifested as haunting absences/presences. At the beginning of the text, they appear in the narrator's imagination through the superposition of two mirrored spaces or cities, Nice and Algiers, as seen in the following passage: 
Avant mes mauvaises pensées, il y a cet été à Nice, ces vacances à Castel Plage (. . .) je crois que tout commence là, dans une confusion des lieux, le sud de la France que je découvre, l'Algérie qui revient par superposition d'images: la mer, la baie, les palmiers, les jeunes garçons qui sifflent sur la Promenade (. . .) J'ai retrouvé mon paradis-les bains chauds et profonds, l'odeur des fleurs, la lumière rose-et j'ai retrouvé mon enfer: l'idée d'une force qui étouffe. Je ne suis jamais retournée en Algérie. ${ }^{30}$

Before my bad thoughts, there is that summer in Nice, the holiday at Castel Plage (. . .) I think that everything starts there, in the mixing of two spaces, the South of France that I then discover and an Algeria that resurfaces through the superposition of images: the sea, the bay, the palm trees, young boys whistling on the Promenade (. . .) I regained my paradise-swimming in the warm and deep sea, the perfume of flowers, the pink light-and I regained my hell: the idea of a force that suffocates me. I have never returned to Algeria.

As in the case for Sept Lacs plus au Nord, the awakening of a subject's particular sensory memory becomes the main trigger for the recollection of repressed memories. In Mes mauvaises pensées, it is the memory of a lost Algeria - the paternal space of the narrator - that resurfaces as an ambivalent space of paradise and hell in a moment of 'stillness' encountered in the space of the psychoanalyst's office. In this moment of anamnesis, the space of the French South - Nice - immediately evokes images of another space reminiscent of this Mediterranean city - Algiers - that brings to the surface feelings of guilt of never having returned to Algeria. At the same time, it is primarily at that moment of realization of nonreturn that Algeria stops being a historical or a geographic space for the narrator, becoming instead a haunting memory, but also a prime source of writing. The paternal space of Algeria in Mes mauvaises pensées becomes a site of mythical memory that could be described in Lacanian terms as a 'Eurydice deux fois perdue', as it is lost twice: firstly as the childhood space through the narrator's moving to France, and secondly through the fading of memory and the impossibility of experiencing this space again through the sensory experiences of the body. ${ }^{31}$ Algeria becomes a utopia, a place of fantasy, of paradise lost, but also the genesis of writing. The origins of these spectral hauntings of Algeria can be found in Garçon manqué:

Ma vie algérienne bat hors de la ville. Elle est à la mer, au désert, sous les montagnes de l'Atlas. Là, je m'efface enfin. Je deviens un 
corps sans type, sans langue, sans nationalité. Cette vie est sauvage. Elle est sans voix et sans visage. ${ }^{32}$

My Algerian heart beats outside of the city. It belongs to the sea and the desert at the foot of the Atlas Mountains. Here, my body is erased and becomes unrecognisable. I become a non-descript body, a body without language, without nationality. This life is brutal. It is voiceless and faceless. ${ }^{33}$

As in the novel just cited, in Mes mauvaises pensées, Algeria becomes primarily the place of lost sensuality; it is the place of the narrator's first experiences of the beauty of the female body and of her later discovered homosexuality, experiences embodied in the character of the beautiful, rich Madame B., with whom she stays one summer while her mother is being treated in France. Again, a similar relationship between space, memory and the body, as recovered corporeality though the discovery of one's homosexuality, can be found in Lalonde's text, as discussed previously. Likewise, there exists a clear opposition in Bouraoui's novel between the paternal and maternal heritage or the spaces that produce an identity discourse of duality. In the novel, the maternal space of the provincial town of Rennes situated in Northern France stands in opposition to the paternal space of Algeria. Contrasted with the images of the narrator's memories of Algeria associated with the father, the space of the northern French city associated with the narrator's mother is experienced by her as a space of death. The passage between the cultural space of France and the cultural space of Algeria can only be achieved through a symbolic and embodied passage or transformation in the metropolitan space of Paris. It is only through the appropriation of the metropolitan, contemporary space of Paris that the narrator's identity transformation is made possible, something that has been demonstrated elsewhere by applying a semiotic reading to the text. ${ }^{34}$ Some critics have argued that one can identify in Mes mauvaises pensées a shift from a fractured space of dual identity - as in Bouraoui's earlier novel Garçon manqué - into a composite, third space of identity: a shift at the political level from a position of the fractured/colonized subject to a position of a nomadic/postcolonial subject. ${ }^{35}$ However, the analysis conducted on Boruaoui's texts relating to her Algerian heritage shows that she does not ultimately fully manage to deconstruct the binary relationship France-Algeria. From that perspective, a reconciliation of identity in Bouraoui's earlier novel Garçon manqué is only apparent. Both Algiers and Rennes reemerge as spaces of the divided or fractured self in Mes mauvaises pensées, something that indicates that the feeling of reconciliation of identity described in Garçon manqué was temporary. 
Fundamentally, it is the narrator's real, imagined and symbolic paternal and maternal spaces of Algeria and France that are being deconstructed in the novel: 'je vous dis, tout de suite, je suis de mère française et de père algérien, comme si mes phobies venaient de ce mariage' (I am telling you now my mother is French and my father is Algerian, it's as if my phobias were born from this marriage). ${ }^{36}$ Then, towards the end of the novel, after evoking a scene in which she recalls her and her mother in the appartement de la rue $X$, the narrator concludes that she is inevitably torn between two spaces and an in-between space that she will need to cross: 'Alors se superposent nos deux lieux, l'Algérie sur la France puis la France sur l'Algérie' (Then there is a superposition of the two places, of Algeria over France, and of France over Algeria). ${ }^{37}$

The narrator's childhood memories are called to the surface again in a moment of 'stillness'. At the end of Bouraoui's novel, the narrator's family memory is reawakened in another scene in which sensory memory is provoked; while walking through the street of Roi-de-Sicile in Paris and passing by an Oriental bakery, the narrator suddenly accedes to the space of corporeal memory below the level of consciousness, concluding that her body remembers the thing she thought she had lost when she exclaims, 'mon corps a la mémoire que j'ai perdu' (my body possesses a memory I have lost). ${ }^{38}$ The question, however, remains open as to how to piece these memories together again, as shown in the following passage: 'Je ne me souviens pas de mon père entre ses deux parents, je devrais superposer les maisons de Rennes et de Jijel. Je devrais mélanger les deux jardins de mon enfance' (I don't remember my father between his own parents, I would have to merge the houses of Rennes and of Jijel. I would have to mix together the two gardens of my childhood). Neither in Paris nor in Nice can the narrator reclaim her cosmopolitan and lesbian identity. Instead, she regains her full identity in the North American town of Provincetown, where she is able to liberate herself from the dual FrancoAlgerian heritage and is free to embrace her (homo)sexuality: 'Je ne confonds rien à Provincetown, je sais ce que je suis, je sais ce que je désire', asserts the narrator (Everything is clear to me in Provincetown, I know what I am, I know what I desire). ${ }^{39}$

\section{Conclusion}

I have used the example of Bouraoui's and Lalonde's postcolonial writing about native space in order to try and offer a comparative analysis of the language of memory and its construction through the trope of haunting 
in the postcolonial francophone context in the case of two authors of mixed heritage. I have argued that in both of the auto-fictional narratives analyzed, this language is generated by a series of memorial traces expressed as ghostly presences/absences recovered from and through the repressed memories of the authors' native spaces in moments of 'stillness'. Both Lalonde's and Bouraoui's text reminds us that it is through this type of awakening of sensory memory in moments of 'stillness' that the reappropriation of one's own identity or history can really begin to take place and one can start to make sense of one's own fractured past. As in Lalonde's case, Bouraoui's text Mes mauvaises pensées shows the importance that sensory memory can play in the (de)construction of dual memory and identity that characterizes authors of mixed heritage. More specifically, Bouraoui's excavatory memories of Algeria, a space that she is haunted by, can be viewed as a symptom of 'the return of the repressed'; a similar dynamic is at play in Lalonde's text. Where in Lalonde's text, it is embodied in the image of the Indian, in Bouraoui's novel, it manifests itself through the recurrent appearance of memorial traces as postcolonial hauntings that punctuate all of her texts dealing with Algeria. Algeria becomes a spectre, a haunting absence/presence in her writing, as well as a source of creative inspiration. Ultimately, whilst Lalonde succeeds in recovering the repressed memories of his paternal Amerindian past through a re-inscription and re-mapping of the Amerindian space of the North, Bouraoui does not fully manage to incorporate her Algerian past and the paternal space of Algeria into her contemporary identity. She fails to reconcile her paternal (Algerian) with her maternal (French) heritage, as she can only do so by a symbolic passage through the (post)colonial space of Paris. Instead, her lesbian and cosmopolitan identity is recovered fully through the appropriation of a third space - the North American space of Provincetown. Finally, although they both produce a postcolonial discourse of ambiguity, the two texts selected testify to the creative and regenerative powers of haunting in the literary context.

\section{Notes}

1 The notion of postcolonial ambiguity over postcolonial resistance in francophone postcolonial writing is discussed at length in Jasmina Bolfek-Radovani, Geo/graphies of Loss: Space, Place and Spatial Loss in North African and Canadian Writing in French (Erlangen: Lambert Academic Publishing, 2015), where I analyze a number of texts belonging to North African and Canadian writing in French.

2 Pascal Blanchard, Nicolas Bancel, Sandrine Lemaire, La Fracture coloniale: La Société française au prisme de l'héritage colonial (Paris: La Découverte/Poche, 2006; 1st ed. 2005), 10. 
3 As Blanchard, Bancel and Lemaire argue in the introduction to their work, the year 2005 (and the years preceding it) saw an unprecedented level of 'politicisation of memory' around the question of colonial history in France. The high number of studies on colonial history coming from intellectual elites and university circles, the flourishing interest in this question in the print and broadcast media, as well as the 2005 French colonialism law known as 'la loi du 23 février 2005' and the ensuing protests and debates, were not coincidental; instead, they should be viewed as a sign of France's institutionalized colonial discourse and nostalgie coloniale, and as symptoms of a retour du refoulé that are a consequence of the country's occultation of its own colonial past. Indeed, this 'institutionalised forgetting' of colonial history has not only resulted in the formation and confrontation of competing and contesting memories, it has also shaped France's collective identity and the way in which it constructs its narrative on national history.

4 The case of Albert Camus and the controversy surrounding his views on the Algerian War of Independence testify to the complexity of the construction of multiple Franco-Algerian histories and memories. Camus was born in Algeria as a pied-noir and some postcolonial critics regard his work as belonging to French colonial writing. Nina Bouraoui refers to Camus's work in her novel, indirectly reclaiming his writing as postcolonial.

5 Nadia Seremetakis, ed., The Senses Still: Perception and Memory as Material Culture in Modernity, (Chicago: University of Chicago Press, 1994), 12.

6 Robert Lalonde, La Belle Épouvante (Montréal: Les Quinze éditeur, 1981).

7 'Rencontre with Lalonde', Radio-France Canada, https://ici.radio-canada.ca.

8 Lalonde's texts that explore the theme of Amerindian identity are: Le Dernier Été des Indiens (Paris: Éditions du Seuil, 1982); Le Fou du père (Montréal: Editions du Boréal, 1988); Sept Lacs plus au Nord (Paris: Éditions du Seuil, 1993); Iotékha (Montréal: Editions du Boréal, 2004).

9 Lalonde's father is a Métis of Mohawk lineage. The Mohawk are a tribe of the Iroquois confederacy (consisting of five tribes) and are mainly located in southwest Québec and south Ontario. Their native language is Kanien'kéha
(Latin script is used) and it belongs to the Iroquoian group of Amerindian languages.

10 See, for example, the film by Alanis Obomsawn from 1993: Kanehsatake: 270 Years of Resistance, http://www.nfb .ca/film/kanehsatake_270_years_of _resistance/. Anglophone Aboriginal writers have also covered the Oka crisis: Lee Marade, Sundogs; Jeannette Armstrong, Indian Summer; Beth Cuthand, Seven Songs for Uncle Louis. Eva-Marie Kröller, ed., Cambridge Companion to Canadian Literature (Cambridge: Cambridge UP, 2017), 43.

11 See, for example, the articles published on Le Devoir website at the time of the 20th anniversary of the Oka crisis.

12 Robert Lalonde, interview with Marie-Claire Girard, Le Devoir, January 16, 1993.

13 All English translations are my own, unless otherwise indicated.

14 Lalonde, interview with Sylvie Saint-Jacques, La Presse, April 15, 2007.

15 Lalonde, Sept Lacs plus au Nord (Paris: Editions du Seuil, 1993), 15.

16 Lalonde, Sept Lacs plus au Nord, 15.

17 Seremetakis, ed., The Senses Still, 14.

18 Seremetakis, ed., The Senses Still, 1-19.

19 Lalonde, Sept Lacs plus au Nord, 23.

20 A similar thematic connection is implied in Sandra Hobbs's article, 'L'Autochtone dans Le Dernier Été des Indiens de Robert Lalonde: ou comment passer de la grande à la petite noirceur', International Journal of Canadian Studies 41 (2010): 248, doi: http://dx.doi.org/10.7202/044169ar.

21 Lalonde, Sept Lacs plus au Nord, 90.

22 Zach Parrott, 'Indigenous People: Religion and Spirituality', The Canadian Encyclopedia Online (2015), http://www .thecanadianencyclopedia.ca/en/article /religion-of-aboriginal-people/.

23 Michael F. O'Riley, 'Postcolonial Haunting: Anxiety, Affect, and the Situated Encounter', Postcolonial Text 3:4 (2007): 1, http://postcolonial.org/index .php/pct/article/view/728/496.

24 According to the author: 'while the turn to place frequently enables a recording of history, it often produces complex dilemmas for those choosing to evoke occulted colonial histories'. O'Riley, 'Postcolonial Haunting', 2.

25 Nina Bouraoui's texts dealing with the Algerian theme are: La Voyeuse interdite (Paris: Flammarion, 1991); Le Jour du séisme (Paris: Stock, 1999); Garçon 
manqué (Paris: Stock, 2000); Mes mauvaises pensées (Paris: Stock, 2005); Sauvage (Paris: Stock, 2011).

26 Rosalia Bivona, 'Nina Bouraoui: une écriture migrante en quête de lieu', Littérature des Immigrations, 2, Exils croisés, Perspectives Comparatistes (Paris: L'Harmattan, 1995), 125-136.

27 Bouraoui, Mes mauvaises pensées (Paris: Stock, 2005), 143.

28 Bouraoui, Mes mauvaises pensées, 200.

29 Nina Bouraoui, Garçon manqué (Paris: Stock, 2005), 20. English translation taken from Tomboy, translated by Marjorie Attignol Salvodon and Jehanne-Marie Gavarini, Lincoln and London: University of Nebraska Press, 2007, 11.

30 Bouraoui, Mes mauvaises pensées, 13-14.

31 Jacques Lacan, Les Quatre concepts fondamentaux de la psychanalyse (Paris: Editions du Seuil, 1973), 33-34.

32 Bouraoui, Garçon manqué, 9.

33 Nina Bouraoui, Tomboy, translated by translated by Marjorie Attignol Salvodon and Jehanne-Marie Gavarini, Lincoln and London: University of Nebraska Press, 2007, 4.

\section{Bibliography}

Armstrong, Jeannette. 'Indian Summer' in Voices: Being Native in Canada. Linda Jaine and Drew Hayden Taylor, eds. (Saskatoon: University of Saskatchewan, 1992).

Bivona, Rosalia. 'Nina Bouraoui: une écriture migrante en quête de lieu', Littérature des Immigrations, 2, Exils croisés, Perspectives Comparatistes (Paris: L'Harmattan, 1995).

Blanchard, Pascal, Nicolas Bancel and Sandrine Lemaire. La Fracture coloniale: $L a$ Société française au prisme de l'héritage colonial (Paris: La Découverte/Poche, 2006; 1st ed. 2005).

Bolfek-Radovani, Jasmina. Geo/graphies of Loss: Space, Place and Spatial Loss in North African and Canadian Writing in French (Erlangen: Lambert Academic Publishing, 2015).

Bouraoui, Nina. La Voyeuse interdite (Paris: Flammarion, 1991).

Bouraoui, Nina. Le Jour du séisme (Paris: Stock, 1999).
34 Jasmina Bolfek-Radovani, Geo/graphies of Loss: Space, Place and Spatial Loss in North African and Canadian Writing in French (Erlangen: Lambert Academic Publishing, 2015).

35 See Helena Vassallo, 'La mémoire dans la peau: Memory, identity and trauma in Nina Bouraoui's Garcon manqué (paper presented at the Society for French Studies' 48th Annual Conference, Birmingham, United Kingdom, July 2-4, 2007). The relationship between 'life narrative', postcolonial memory and the body is discussed in Helen Vassallo, 'Wounded Storyteller: Illness as Life Narrative in Nina Bouraoui's Garçon manqué', Forum for Modern Language Studies 43:1 (2007): 46-56, https://academic.oup.com/fmls /article/43/1/46/552934.

36 Bouraoui, Mes mauvaises pensées, (Paris: Stock, 2005), 18.

37 Bouraoui, Mes mauvaises pensées, 254-255.

38 Bouraoui, Mes mauvaises pensées, 255.

39 Bouraoui, Mes mauvaises pensées, 190. Provincetown, Massachusetts, is a coastal resort town and a popular vacation destination with gay men and lesbians.

Bouraoui, Nina. Garçon manqué (Paris: Stock, 2000).

Bouraoui, Nina. Mes mauvaises pensées (Paris: Stock, 2005).

Bouraoui, Nina. Tomboy, translated by Marjorie Attignol Salvodon and Jehanne-Marie Gavarini. (Lincoln and London: University of Nebraska Press, 2007).

Bouraoui, Nina. Sauvage (Paris: Stock, 2011).

Cuthand, Beth. Seven Songs for Uncle Louis. In Native Poetry in Canada: A Contemporary Anthology, (eds) Jeannette Armstrong and Lally Grauer (Guelph: Broadview Press, 2001).

Hobbs, Sandra. 'L'Autochtone dans Le Dernier Été des Indiens de Robert Lalonde: ou comment passer de la grande à la petite noirceur', International Journal of Canadian Studies 41 (2010): 248, doi: http://dx.doi.org/10.7202 /044169ar.

Kröller, Eva-Marie, ed. Cambridge Companion to Canadian Literature (Cambridge: Cambridge University Press, 2017). 
Lalonde, Robert. La Belle Épouvante (Montréal: Les Quinze éditeur, 1981).

Lalonde, Robert. "Rencontre with Lalonde", Radio-France Canada, https://ici.radio -canada.ca.

Lalonde, Robert. Le Dernier Été des Indiens (Paris: Éditions du Seuil, 1982).

Lalonde, Robert. Le Fou du père (Montréal: Editions du Boréal, 1988).

Lalonde, Robert. Interview with Marie-Claire Girard, Le Devoir, January 16, 1993.

Lalonde, Robert. Sept Lacs plus au Nord (Paris: Éditions du Seuil, 1993).

Lalonde, Robert. Iotékha (Montréal: Editions du Boréal, 2004).

Lalonde, Robert. Interview with Sylvie Saint-Jacques, La Presse, April 15, 2007.

Maracle, Lee. Sundogs (Penticton, BC: Theytus Books, 1992).

O’Riley, Michael F. 'Postcolonial Haunting: Anxiety, Affect, and the Situated Encounter', Postcolonial Text 3:4 (2007): 1, http://postcolonial.org /index.php/pct/article/view/728/496.
Parrott, Zach. 'Indigenous People: Religion and Spirituality', The Canadian Encyclopedia Online (2015), http:// www.thecanadianencyclopedia.ca /en/article/religion-of-aboriginal -people.

Seremetakis, Nadia, ed. The Senses Still: Perception and Memory as Material Culture in Modernity, (Chicago: University of Chicago Press, 1994).

Vassallo, Helen. 'La mémoire dans la peau: Memory, identity and trauma in Nina Bouraoui's Garcon manqué' (paper presented at the Society for French Studies' 48th Annual Conference, Birmingham, United Kingdom, July 2-4, 2007).

Vassallo, Helen. 'Wounded Storyteller: Illness as Life Narrative in Nina Bouraoui's Garçon manqué, Forum for Modern Language Studies 43:1 (2007): 46-56. https://academic.oup.com/fmls /article/43/1/46/552934.

\section{Note on Contributor}

Jasmina Bolfek-Radovani is a visiting research fellow at the University of Westminster. A graduate of the same institution, she holds a $\mathrm{PhD}$ in francophone literary and cultural studies. Her research interests include the study of literary and cultural productions of space in the area of francophone Maghreb and Canada and their relationship to the contemporary. She has published several articles in peer-reviewed journals and has been invited as one of the contributors for the special issue of Nottingham French Studies, UK Perspectives on Francophone Canada (edited by Rosemary Chapman, 2016). She has given a number of conference presentations, both nationally and internationally. Her work based on her PhD thesis, Geo/graphies of Loss: Space, Place and Spatial Loss in North African and Canadian Writing in French, was published in 2015 (Lambert Academic Publishing, Erlangen, 2015). Jasmina is also a poet. Her multilingual poetry has been published in the UK, Canada and Croatia.

\section{Conflict of Interests}

The author declares that there are no conflicts of interests with this work. 